\title{
Conhecimento dos graduandos de oitavo semestre do curso de Enfermagem do Centro Universitório Nove de Julho (Uninove) sobre parada cardiorrespiratória
}

Heliandra Holanda Reis

Uninove. São Paulo - SP [Brasil]

heliandrahreis@yahoo.com.br

Gláucia Maria Medeiro Ferreira Hospital São Luís. São Paulo - SP [Brasil]
A maioria das vítimas de parada cardiorrespiratória (PCR) morre por falta de atendimento emergencial adequado, que deve ser rápido e organizado para evitar danos neurológicos (pós-PCR) aos pacientes. Esses procedimentos são decisivos para um atendimento eficiente e eficaz, prevenindo complicações irreversíveis que podem levar o paciente ao óbito. Este estudo buscou identificar o conhecimento dos estudantes do último semestre do curso de Enfermagem da Uninove quanto ao atendimento a PCR, utilizandose a técnica quantitativo-descritiva, com 172 graduandos do oitavo semestre do referido curso, nas unidades Vila Maria (VM) e Memorial (MM). Constatou-se que 63\% das respostas foram corretas, e 37\%, erradas. A análise dos dados possibilitou identificar que, embora representada por uma minoria dos respondentes, é grande a quantidade de erros; entretanto, os graduandos em estudo estão teoricamente capacitados a atender indivíduos com PCR.

Palavras-chave: Infarto do miocárdio. Parada cardíaca. Ressuscitação cardiopulmonar. 


\section{Introdução}

Os profissionais especialistas em atendimento emergencial são unânimes em afirmar que, se o Brasil seguisse o exemplo dos Estados Unidos e de alguns países europeus, dispondo de uma lei federal que obrigasse a instalação de equipamentos, tais como os desfibriladores externos automáticos, em locais públicos, muitas vidas poderiam ser salvas. No entanto, legislação específica existe somente nas cidades de Curitiba e Londrina, no Estado do Paraná (BERGAMO, 2004).

O coração é o órgão responsável pelo bombeamento de sangue no corpo, em formato cônico-arredondado, situado entre os pulmões, subdividido em átrios e ventrículos direito e esquerdo, cuja função principal é o envio do sangue, rico em oxigênio, para todas as células do organismo (BIBLIOMED, 2002).

A PCR consiste na cessação súbita dos batimentos cardíacos e respiratórios, cujos sinais são a ausência dos movimentos de respiração e de pulso, palidez, pele fria e úmida, presença de cianose de extremidades e dilatação pupilar (BIBLIOMED, 1998).

A PCR requer um atendimento emergencial, em que o tempo decorrido entre o início do evento, a instauração de medidas de suporte e o adequado atendimento baseado em protocolos específicos constituem fatores decisivos para o sucesso terapêutico. Muito se comenta sobre ocorrências de PCR em que o indivíduo chega a óbito em decorrência de o atendimento de primeiros socorros ter sido prestado por leigos ou por profissionais de saúde com dificuldades práticas de procedimento (ZAGO et al., 1999).

A sobrevida é reduzida entre $7 \%$ e $10 \%$ a cada minuto, após uma PCR, e poucas tentativas de ressuscitação cardiopulmonar (RCP) têm êxito depois dos dez minutos iniciais. A morte por PCR não é inevitável. Se a população estiver orientada para chamar, com rapidez, a equipe de atendimento treinada para oferecer suporte básico até a chegada do desfibrilador mais próximo, muitas vidas poderão ser salvas (INSTITUTO DO CORAÇÃO, 2003).

$\mathrm{O}$ atendimento à PCR deve seguir um adequado e rigoroso procedimento de enfermagem, justamente porque envolve a condição de risco de morte; por isso, é de vital importância que o enfermeiro que presta assistência ao indivíduo em PCR tenha prática e experiência nesse tipo de atendimento, que só poderão ser adquiridas mediante orientação e treinamento adequados (ZAGO et al., 1999).

A partir deste estudo, realizado para verificar o conhecimento dos alunos de oitavo semestre do curso de Enfermagem do Centro Universitário Nove de Julho (Uninove) acerca do atendimento a indivíduos que sofreram uma PCR, surgiu uma dúvida: será que os graduandos de Enfermagem estão preparados para atender corretamente a esse tipo de ocorrência?

\section{PCR: definição e conceito}

A PCR é a cessação dramática e súbita da circulação, da respiração e dos batimentos cardíacos em um indivíduo, e sempre constituiu desafio para a área da saúde. Representa uma emergência extrema, que resulta em lesão cerebral irreversível e morte, se as medidas adequadas para o restabelecimento do fluxo sanguíneo e da respiração não forem tomadas rapidamente $(\mathrm{ZOCH}$ et al., 2000; INSTITUTO DO CORAÇÃO, 2003).

A morte cerebral tem início entre os primeiros quatro e seis minutos da PCR, podendo ser revertida em um curto intervalo de tempo, na maioria das vítimas, graças ao choque elétrico provocado pela utilização do desfibrilador, que restabelece o ritmo cardíaco normal. (INSTITUTO DO CORAÇÃO, 2003).

\subsection{Epidemiologia}

$\mathrm{O}$ índice de sucesso do atendimento à vítima de PCR depende do tempo transcorrido 
entre a solicitação do socorro e a desfibrilação, que varia de acordo com a comunidade em que ocorre o evento e com a preparação dos profissionais. Nos Estados Unidos, esse índice de variação é de $3 \%$ nos centros mais movimentados em que o trânsito prejudica a chegada do socorro e, no máximo, de $33 \%$ nos locais mais qualificados para esse tipo de atendimento (MANO, 2005).

Na população geral não-selecionada, a incidência global de morte súbita é de 0,1 a $0,2 \%$ anuais. Expresso em porcentagem, parece irrisório, mas o valor absoluto atinge cerca de 300 mil mortos por ano. Nas populações selecionadas, o valor absoluto de óbitos se reduz, porém o risco relativo permanece elevado. O risco de morte súbita oscila entre 20 e $30 \%$ nos pacientes com fração de ejeção baixa, sintoma clássico da insuficiência cardíaca congestiva (ICC). Essa taxa piora quando associada ao infarto agudo do miocárdio ou à arritmia ventricular (MANO, 2005).

Outra pesquisa ainda revela que cerca de $30 \%$ das tentativas de ressuscitação da PCR são bem-sucedidas e que, dos pacientes que sobrevivem ao procedimento inicial, somente $10 \%$ recuperam-se, sem seqüelas neurológicas ou com graus leves e moderados de incapacidade funcional (SILVA, 1999).

\subsection{Fisiopatologia}

Ao ocorrer uma PCR, se a tentativa de ressuscitação for bem-sucedida, normalmente o indivíduo poderá apresentar seqüelas neurológicas ou alguma incapacidade funcional de grau leve ou moderado. Infelizmente, grande parte desses sobreviventes chega a óbito no primeiro ano, após sua recuperação (SILVA, 1999).

O sistema nervoso central utiliza o metabolismo aeróbio para obter energia, por meio de mecanismos de auto-regulação vascular para garantir continuidade na oferta de oxigenação. Durante a PCR, o cérebro realiza metabolismo anaeróbio, pois a produção de energia, por via metabólica, é inadequada para suprir sua alta demanda. Durante a parada circulatória total, as funções cerebrais se deterioram rapidamente (CUMMINS et al., 1997; WAYNE, 1998).

No início da PCR, ocorre uma rápida perda de consciência, normalmente de 15 segundos (s) e, depois de um minuto, a função do tronco cerebral cessa, a respiração torna-se agônica e as pupilas ficam fixas ou dilatadas. Esse quadro clínico refere-se às alterações bioquímicas da depleção de oxigênio, ocorridas após os 15 segundos. A glicose esgota-se em quatro ou cinco minutos (CUMMINS et al., 1997).

Apesar da evidência de que alguns neurônios possam suportar períodos prolongados de anóxia (até 20 minutos), não existe terapia que garanta a recuperação neurológica completa após uma PCR com mais de cinco minutos de duração. Conseqüentemente, nessas condições, não há como evitar o desenvolvimento da síndrome pós-reanimação, na qual a reperfusão do cérebro produziria dano cerebral (KNOBEL,1998; CUMMINS et al., 1997).

Durante esse evento, há uma hipoperfusão variável atribuída a vasoconstrição, redução de conformação da hemácia, agregação plaquetária, edema celular pericapilar e anormalidades do fluxo de íon cálcio. A elevação da pressão intracraniana não tem sido considerada. A inabilidade de recuperação do fluxo sanguíneo cerebral, após um período significante de sua interrupção, denomina-se fenômeno de não-refluxo e pode durar de 18 a 24 horas. Após esse período, o fluxo sanguíneo regional tanto pode melhorar, levando a uma recuperação funcional, quanto declinar, causando dano isquêmico progressivo ou morte celular (CUMMINS et al., 1997).

A acidose tecidual ocorrida pela isquemia é aumentada na reperfusão, ocasionando dano e morte neuronal. A reperfusão pode piorar o edema cerebral citotóxico decorrente da disfunção da membrana, que ocorre durante a isquemia. Apesar da restauração da integridade da membrana após a reperfusão, pode-se desen- 
volver edema vasogênico pela presença de dano endotelial (TIMERMAN et al., 2001).

O hipermetabolismo prolongado, após parada cardíaca cerebral normotérmica, desequilibra a relação entre a oferta e o consumo de oxigênio no cérebro, apontando para uma provável internação para indução da hipotermia. Estudos recentes indicam que a hipotermia de 34 graus Celsius $\left({ }^{\circ} \mathrm{C}\right)$ pode minimizar o dano cerebral pós-isquêmico, sem induzir efeitos colaterais importantes (CUMMINS et al., 1997).

\subsection{Atendimento emergencial}

Atualmente, para que haja êxito no atendimento a vítimas de PCR, necessita-se de RCP e desfibrilação precoce, o que depende também da disponibilidade e funcionalidade do equipamento de RCP, que deve estar pronto para imediata utilização (SOCIEDADE BRASILEIRA DE CARDIOLOGIA, 2003).

No atendimento emergencial à PCR, as chances de sucesso na técnica de ressuscitação são sempre bem maiores se o processo for iniciado dentro de um período que envolve os primeiros quatro minutos do colapso (MANO, 2005). O atendimento emergencial ao indivíduo que sofreu PCR divide-se em duas categorias: pré-hospitalar e hospitalar.

O atendimento pré-hospitalar é a assistência prestada, num primeiro nível de atenção, aos portadores de quadros agudos de natureza clínica, traumática ou psiquiátrica, que ocorrem fora do ambiente hospitalar, podendo acarretar sofrimento, seqüelas ou mesmo a morte (MELO, VASCONCELLOS, TONELLI, 2004).

Para o atendimento pré-hospitalar, o Ministério da Saúde lançou o Serviço de Atendimento Móvel de Urgência (Samu), no intuito de organizar os serviços de atendimento emergencial de vários gêneros fora do ambiente hospitalar. Esse órgão atende às urgências de natureza traumática, clínica, pediátrica, cirúrgica, gineco-obstétrica e de saúde mental da população brasileira. No atendimento ao in- divíduo acometido de PCR, o Samu presta os primeiros socorros, prevenindo lesões. (MELO, VASCONCELLOS, TONELLI, 2004).

No ambiente hospitalar, a RCP é um procedimento emergencial rotineiro, aplicado em todos os pacientes com PCR e realizado mediante seu consentimento presumido, visto que a sua não-realização tornará a morte inevitável (ZOCH et al., 2000).

Muitas dúvidas ainda existem a respeito de quais pacientes teriam bons resultados com a técnica de ressuscitação. É importante que haja melhor entendimento sobre sua eficácia e taxas de sobrevida para a avaliação do sucesso das manobras de RCP e da evolução dos pacientes. Essas informações são decisivas para que as instituições planejem as técnicas que serão adotadas (ZOCH et al., 2000).

No tratamento da PCR, são utilizadas as seguintes drogas: a adrenalina, a atropina e os antiarrítimicos (lidocaína, amiodarona e procainamida), esses também administrados após a manobra de ressuscitação para prevenir a recidiva da FV (MANO, 2005).

\section{Método}

A pesquisa visou à análise quantitativodescritiva de determinadas informações para que os resultados pudessem exibir uma mensuração precisa e confiável, permitindo que, a partir deles, fossem elaboradas estatísticas que atendessem a uma verificação numérica da hipótese (LAKATOS; MARCONI, 2001).

Na pesquisa descritiva, há o estudo e o levantamento das informações sobre o tema para auxiliar na formulação do problema a ser investigado. Esse tipo de pesquisa tem como objetivo primordial a descrição das características de determinadas populações ou fenômenos, ou ainda o estabelecimento de possíveis relações entre variáveis, cuja relevância está na adoção de técnicas padronizadas de coleta de dados, tal como o questionário aqui empregado (SANTOS; ROSSI; JARDILINO, 2000; GIL, 2002). 


\subsection{População e amostra para coleta de dados}

A população da pesquisa compôs-se de graduandos do oitavo semestre do curso de Enfermagem da Uninove - instituição de ensino superior, particular de grande porte -, das unidades Vila Maria (VM) e Memorial (MM), localizadas, respectivamente, nas Zonas Norte e Oeste da cidade de São Paulo (SP), compreendendo 172 indivíduos de diferentes turnos, sem idade predeterminada e de ambos os sexos, representando aproximadamente $72 \%$ do total de alunos do curso.

\subsection{Aspectos éticos}

A pesquisa foi avaliada pelo Comitê de Ética em Pesquisa da Uninove, que aprovou o projeto. Antes da aplicação do questionário, apresentou-se a cada um dos graduandos um "Termo de Consentimento Livre e Esclarecido", com base nas exigências éticas gerais de qualquer atividade científica relacionada ao ser humano, pautando-se pelas diretrizes e normas da Resolução 196/96, do Conselho Nacional de Saúde (SEVERINO, 2000).

\subsection{Instrumento, procedimento e perío- do da coleta de dados}

Para a coleta dos dados, foi aplicado um questionário (Anexo) com dez perguntas padronizadas e fechadas, apresentando opções de respostas. Os dados foram coletados durante o período de $1^{\circ}$ a 30 de setembro de 2005, após a aprovação do projeto pelo Comitê de Ética.

\section{Resultados}

Para estudar a associação entre o número de acertos e a unidade ou período, empregouse o modelo de análise de variância com dois fatores fixos. Os dados basearam-se nas características das respostas obtidas por questão, divididos por unidade, período e acertos, conforme as tabelas e os gráficos a seguir.

Tabela l: Distribuição de respostas (unidade VM)

\begin{tabular}{|c|c|c|c|c|c|}
\hline & $\begin{array}{c}\text { Em } \\
\text { branco }\end{array}$ & a & b & c & d \\
\hline \multirow{2}{*}{$\begin{array}{l}\text { Questão } \\
1\end{array}$} & 0 & 64 & 5 & 34 & 8 \\
\hline & $0,0 \%$ & $57,7 \%$ & $4,5 \%$ & $30,6 \%$ & $7,2 \%$ \\
\hline \multirow{2}{*}{$\begin{array}{c}\text { Questão } \\
2\end{array}$} & 0 & 2 & 105 & 0 & 4 \\
\hline & $0,0 \%$ & $1,8 \%$ & $94,6 \%$ & $0,0 \%$ & $3,6 \%$ \\
\hline \multirow{2}{*}{$\begin{array}{c}\text { Questão } \\
3\end{array}$} & 4 & 100 & 2 & 3 & 2 \\
\hline & $3,6 \%$ & $90,1 \%$ & $1,8 \%$ & $2,7 \%$ & $1,8 \%$ \\
\hline \multirow{2}{*}{$\begin{array}{c}\text { Questão } \\
4\end{array}$} & 1 & 6 & 39 & 51 & 14 \\
\hline & $0,9 \%$ & $5,4 \%$ & $35,1 \%$ & $45,9 \%$ & $12,6 \%$ \\
\hline \multirow{2}{*}{$\begin{array}{l}\text { Questão } \\
5\end{array}$} & 3 & 4 & 11 & 31 & 62 \\
\hline & $2,7 \%$ & $3,6 \%$ & $9,9 \%$ & $27,9 \%$ & $55,9 \%$ \\
\hline \multirow{2}{*}{$\begin{array}{c}\text { Questão } \\
6\end{array}$} & 5 & 2 & 9 & 83 & 12 \\
\hline & $4,5 \%$ & $1,8 \%$ & $8,1 \%$ & $74,8 \%$ & $10,8 \%$ \\
\hline \multirow{2}{*}{$\begin{array}{c}\text { Questão } \\
7\end{array}$} & 1 & 2 & 106 & 1 & 1 \\
\hline & $0,9 \%$ & $1,8 \%$ & $95,5 \%$ & $0,9 \%$ & $0,9 \%$ \\
\hline \multirow{2}{*}{$\begin{array}{l}\text { Questão } \\
8\end{array}$} & 4 & 28 & 48 & 14 & 17 \\
\hline & $3,6 \%$ & $25,2 \%$ & $43,2 \%$ & $12,6 \%$ & $15,3 \%$ \\
\hline \multirow{2}{*}{$\begin{array}{l}\text { Questão } \\
9\end{array}$} & 1 & 7 & 21 & 22 & 60 \\
\hline & $0,9 \%$ & $6,3 \%$ & $18,9 \%$ & $19,8 \%$ & $54,1 \%$ \\
\hline \multirow{2}{*}{$\begin{array}{l}\text { Questão } \\
10\end{array}$} & 4 & 20 & 60 & 24 & 3 \\
\hline & $3,6 \%$ & $18,0 \%$ & $54,1 \%$ & $21,6 \%$ & $2,7 \%$ \\
\hline
\end{tabular}

Fonte: As autoras.

A questão que obteve o maior número de acertos $(95,5 \%)$ foi a questão 7 , que se refere ao conhecimento sobre medicamentos, seguida das questões $2(94,6 \%)$ e $3(90,1 \%)$, referentes a reconhecimento básico de uma parada cardíaca e resistência do sistema neurológico do paciente, respectivamente. A que obteve menor índice de acertos na unidade VM foi a questão $8(25,2 \%)$, que retrata uma situação de atendimento de emergência, sendo explorados a habilidade e o conhecimento teórico do enfermeiro. Apesar disso, a questão referente ao uso do desfibrilador, questão $6(74,8 \%)$, obteve um número de acertos significativo. 
A questão com o maior índice de acertos pelos estudantes da unidade MM foi a 3 $(96,7 \%)$, referente ao reconhecimento de uma parada cardíaca, seguida das questões $2(95,1 \%)$ e $7(95,1 \%)$ que abordam, respectivamente, os assuntos: reconhecimento de uma parada e fármaco. Apesar desses índices, essa unidade foi a que obteve o menor número de acertos para questões relativas a situações de atendimento de emergência (questão 8 , com 23\%), cuidados de enfermagem na administração de drogas (questão 4, com 31,1\%) e conhecimento e interpretação de eletrocardiograma (questão $10,42,6 \%$ ).

Analisando-se as respostas por turno, considerando as duas unidades, obteve-se que o maior índice de acertos foi para a questão 7 $(96,8 \%)$, sobre fármacos, seguida da questão 3 $(90,3 \%)$, referente ao reconhecimento de uma

Tabela 2: Distribuição de respostas (unidade MM)

\begin{tabular}{|c|c|c|c|c|c|}
\hline & $\begin{array}{c}\text { Em } \\
\text { branco }\end{array}$ & a & b & c & d \\
\hline \multirow{2}{*}{$\begin{array}{c}\text { Questão } \\
1\end{array}$} & 2 & 44 & 2 & 12 & 1 \\
\hline & $3,3 \%$ & $72,1 \%$ & $3,3 \%$ & $19,7 \%$ & $1,6 \%$ \\
\hline \multirow{2}{*}{$\begin{array}{l}\text { Questão } \\
2 \\
\end{array}$} & 0 & 2 & 58 & 0 & 1 \\
\hline & $0,0 \%$ & $3,3 \%$ & $95,1 \%$ & $0,0 \%$ & $1,6 \%$ \\
\hline \multirow{2}{*}{$\begin{array}{c}\text { Questão } \\
3\end{array}$} & 0 & 59 & 2 & 0 & 0 \\
\hline & $0,0 \%$ & $96,7 \%$ & $3,3 \%$ & $0,0 \%$ & $0,0 \%$ \\
\hline \multirow{2}{*}{$\begin{array}{c}\text { Questão } \\
4\end{array}$} & 2 & 0 & 21 & 19 & 19 \\
\hline & $3,3 \%$ & $0,0 \%$ & $34,4 \%$ & $31,1 \%$ & $31,1 \%$ \\
\hline \multirow{2}{*}{$\begin{array}{l}\text { Questão } \\
5\end{array}$} & 1 & 4 & 5 & 17 & 34 \\
\hline & $1,6 \%$ & $6,6 \%$ & $8,2 \%$ & $27,9 \%$ & $55,7 \%$ \\
\hline \multirow{2}{*}{$\begin{array}{l}\text { Questão } \\
6\end{array}$} & 0 & 2 & 5 & 52 & 2 \\
\hline & $0,0 \%$ & $3,3 \%$ & $8,2 \%$ & $85,2 \%$ & $3,3 \%$ \\
\hline \multirow{2}{*}{$\begin{array}{l}\text { Questão } \\
7\end{array}$} & 1 & 0 & 58 & 2 & 0 \\
\hline & $1,6 \%$ & $0,0 \%$ & $95,1 \%$ & $3,3 \%$ & $0,0 \%$ \\
\hline \multirow{2}{*}{$\begin{array}{l}\text { Questão } \\
8\end{array}$} & 3 & 14 & 24 & 13 & 7 \\
\hline & $4,9 \%$ & $23,0 \%$ & $39,3 \%$ & $21,3 \%$ & $11,5 \%$ \\
\hline \multirow{2}{*}{$\begin{array}{l}\text { Questão } \\
9\end{array}$} & 1 & 8 & 8 & 12 & 32 \\
\hline & $1,6 \%$ & $13,1 \%$ & $13,1 \%$ & $19,7 \%$ & $52,5 \%$ \\
\hline \multirow{2}{*}{$\begin{array}{c}\text { Questão } \\
10\end{array}$} & 1 & 5 & 26 & 28 & 1 \\
\hline & $1,6 \%$ & $8,2 \%$ & $42,6 \%$ & $45,9 \%$ & $1,6 \%$ \\
\hline
\end{tabular}

Fonte: As autoras. parada cardíaca. A menor porcentagem de acertos ocorreu na questão $8(25,8 \%)$, sobre situação de atendimento de emergência.

Os alunos do período da tarde, considerando-se as duas unidades, obtiveram maior acerto na questão $2(97,4 \%)$, sobre reconhecimento de uma parada cardíaca, seguida das questões 7 (94,7\%), sobre fármacos, e $3(90,8 \%)$, também sobre reconhecimento de uma parada. O menor índice de acertos ocorreu na questão 8 (23,7\%), sobre atendimento de emergência, seguida das questões $4(34,2 \%)$, dos cuidados na administração de drogas; 9 (42,1\%), do atendimento ao PCR, e $10(48,7 \%)$, a respeito do conhecimento e interpretação de eletrocardiograma.

Os alunos do período noturno, considerando-se as duas unidades, obtiveram maior acerto nas questões 3 e 7 (ambas 95,4\%), referentes aos assuntos: reconhecimento de parada cardíaca e

Tabela 3: Distribuição de respostas (manhã, unidades MM e VM)

\begin{tabular}{|c|c|c|c|c|c|}
\hline & $\begin{array}{c}\text { Em } \\
\text { branco }\end{array}$ & $a$ & $\mathrm{~b}$ & c & $\mathrm{d}$ \\
\hline \multirow{2}{*}{$\begin{array}{c}\text { Questão } \\
1\end{array}$} & 0 & 17 & 1 & 9 & 4 \\
\hline & $0,0 \%$ & $54,8 \%$ & $3,2 \%$ & $29,0 \%$ & $12,9 \%$ \\
\hline \multirow{2}{*}{$\begin{array}{l}\text { Questão } \\
2\end{array}$} & 0 & 1 & 29 & 0 & 1 \\
\hline & $0,0 \%$ & $3,2 \%$ & $93,5 \%$ & $0,0 \%$ & $3,2 \%$ \\
\hline \multirow{2}{*}{$\begin{array}{c}\text { Questão } \\
3\end{array}$} & 1 & 28 & 2 & 0 & 0 \\
\hline & $3,2 \%$ & $90,3 \%$ & $6,5 \%$ & $0,0 \%$ & $0,0 \%$ \\
\hline \multirow{2}{*}{$\begin{array}{l}\text { Questão } \\
4\end{array}$} & 0 & 0 & 8 & 21 & 2 \\
\hline & $0,0 \%$ & $0,0 \%$ & $25,8 \%$ & $67,7 \%$ & $6,5 \%$ \\
\hline \multirow{2}{*}{$\begin{array}{l}\text { Questão } \\
5\end{array}$} & 0 & 1 & 1 & 10 & 19 \\
\hline & $0,0 \%$ & $3,2 \%$ & $3,2 \%$ & $32,3 \%$ & $61,3 \%$ \\
\hline \multirow{2}{*}{$\begin{array}{l}\text { Questão } \\
6\end{array}$} & 4 & 0 & 2 & 21 & 4 \\
\hline & $12,9 \%$ & $0,0 \%$ & $6,5 \%$ & $67,7 \%$ & $12,9 \%$ \\
\hline \multirow{2}{*}{$\begin{array}{c}\text { Questão } \\
7\end{array}$} & 0 & 0 & 30 & 0 & 1 \\
\hline & $0,0 \%$ & $0,0 \%$ & $96,8 \%$ & $0,0 \%$ & $3,2 \%$ \\
\hline \multirow{2}{*}{$\begin{array}{c}\text { Questão } \\
8\end{array}$} & 0 & 8 & 14 & 2 & 7 \\
\hline & $0,0 \%$ & $25,8 \%$ & $45,2 \%$ & $6,5 \%$ & $22,6 \%$ \\
\hline \multirow{2}{*}{$\begin{array}{l}\text { Questão } \\
9\end{array}$} & 0 & 2 & 5 & 1 & 23 \\
\hline & $0,0 \%$ & $6,5 \%$ & $16,1 \%$ & $3,2 \%$ & $74,2 \%$ \\
\hline \multirow{2}{*}{$\begin{array}{l}\text { Questão } \\
10\end{array}$} & 0 & 2 & 23 & 6 & 0 \\
\hline & $0,0 \%$ & $6,5 \%$ & $74,2 \%$ & $19,4 \%$ & $0,0 \%$ \\
\hline
\end{tabular}

Fonte: As autoras. 

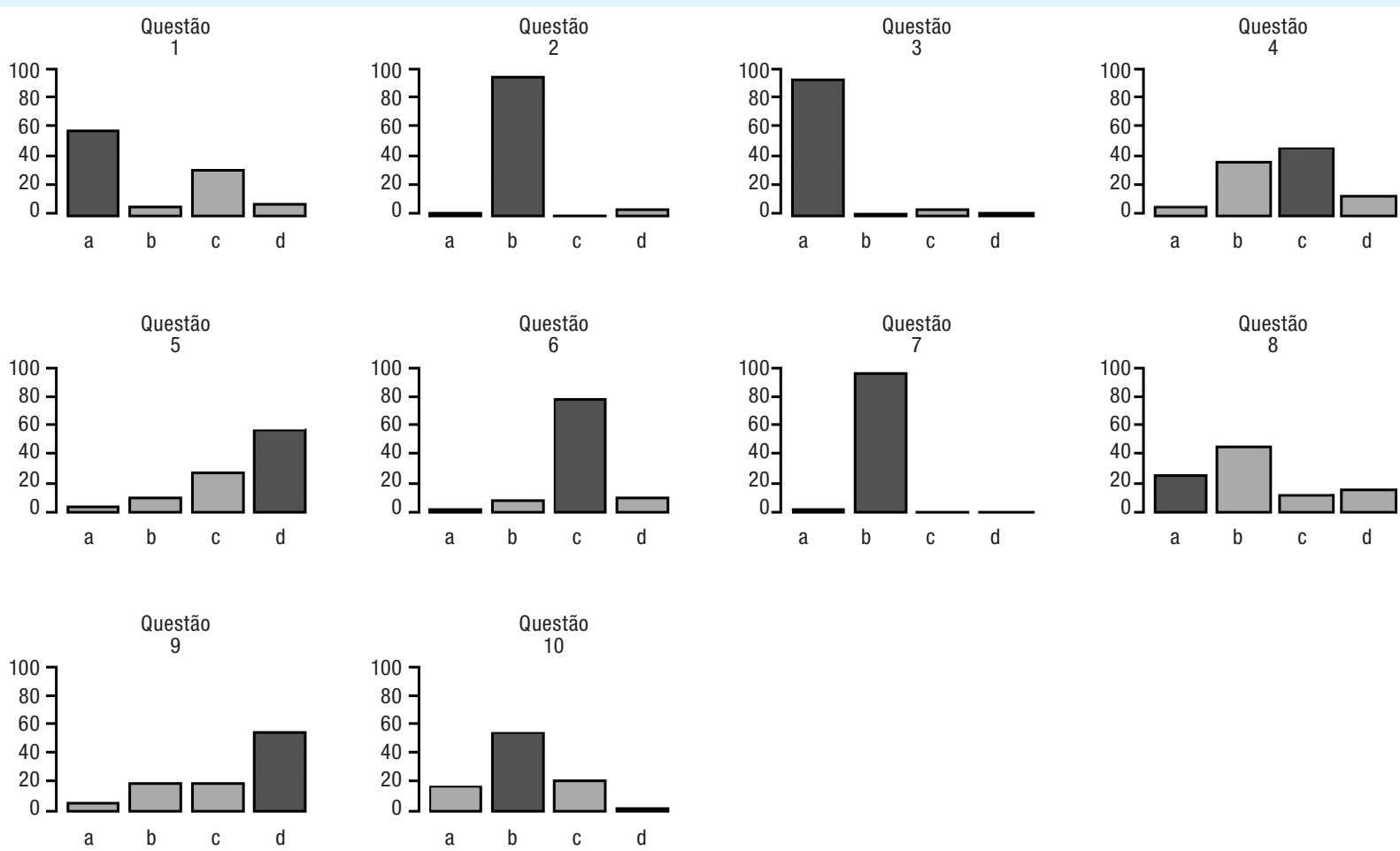

Grófico 1: Acerto de alunos (unidade VM)

Fonte: As autoras.
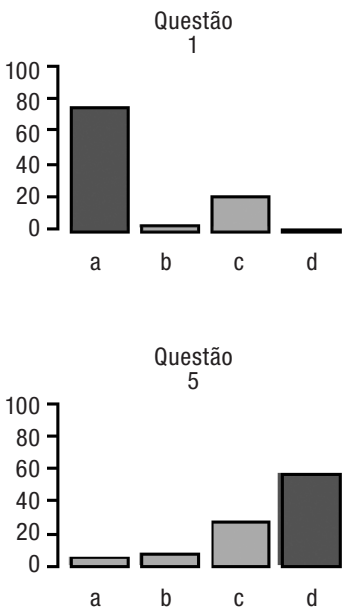

Questão
9

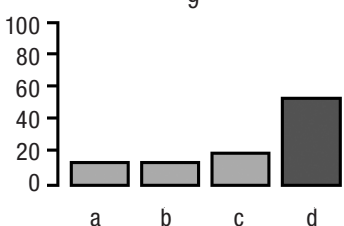

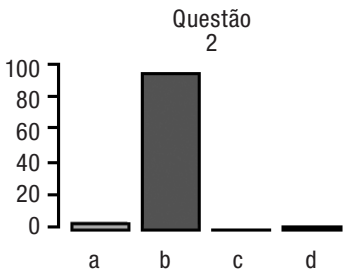
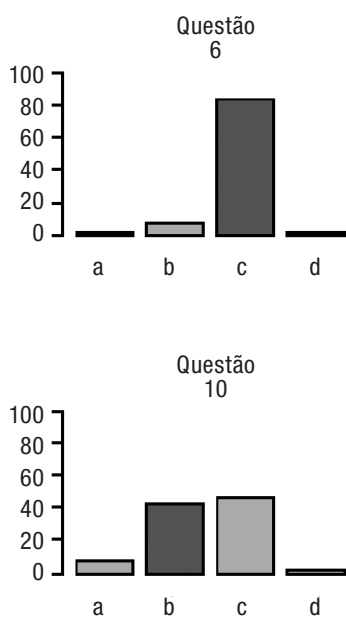
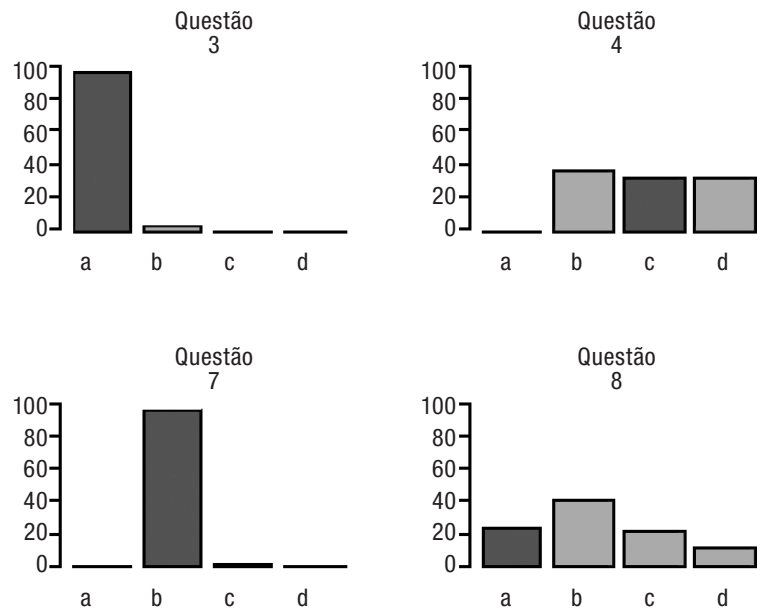

Grófico 2: Acerto de alunos (unidade MM)

Fonte: As autoras. 
Tabela 4: Distribuição de respostas (tarde, unidades MM e VM)

\begin{tabular}{|c|c|c|c|c|c|}
\hline & $\begin{array}{c}\text { Em } \\
\text { branco }\end{array}$ & a & b & c & d \\
\hline \multirow{2}{*}{$\begin{array}{l}\text { Questão } \\
1\end{array}$} & 2 & 45 & 4 & 21 & 4 \\
\hline & $2,6 \%$ & $59,2 \%$ & $5,3 \%$ & $27,6 \%$ & $5,3 \%$ \\
\hline \multirow{2}{*}{$\begin{array}{c}\text { Questão } \\
2\end{array}$} & 0 & 1 & 74 & 0 & 1 \\
\hline & $0,0 \%$ & $1,3 \%$ & $97,4 \%$ & $0,0 \%$ & $1,3 \%$ \\
\hline \multirow{2}{*}{$\begin{array}{c}\text { Questão } \\
3\end{array}$} & 3 & 69 & 2 & 0 & 2 \\
\hline & $3,9 \%$ & $90,8 \%$ & $2,6 \%$ & $0,0 \%$ & $2,6 \%$ \\
\hline \multirow{2}{*}{$\begin{array}{l}\text { Questão } \\
4\end{array}$} & 2 & 2 & 35 & 26 & 11 \\
\hline & $2,6 \%$ & $2,6 \%$ & $46,1 \%$ & $34,2 \%$ & $14,5 \%$ \\
\hline \multirow{2}{*}{$\begin{array}{l}\text { Questão } \\
5\end{array}$} & 4 & 4 & 12 & 18 & 38 \\
\hline & $5,3 \%$ & $5,3 \%$ & $15,8 \%$ & $23,7 \%$ & $50,0 \%$ \\
\hline \multirow{2}{*}{$\begin{array}{l}\text { Questão } \\
6\end{array}$} & 1 & 2 & 8 & 59 & 6 \\
\hline & $1,3 \%$ & $2,6 \%$ & $10,5 \%$ & $77,6 \%$ & $7,9 \%$ \\
\hline \multirow{2}{*}{$\begin{array}{l}\text { Questão } \\
7\end{array}$} & 2 & 1 & 72 & 1 & 0 \\
\hline & $2,6 \%$ & $1,3 \%$ & $94,7 \%$ & $1,3 \%$ & $0,0 \%$ \\
\hline \multirow{2}{*}{$\begin{array}{l}\text { Questão } \\
8\end{array}$} & 5 & 18 & 27 & 14 & 12 \\
\hline & $6,6 \%$ & $23,7 \%$ & $35,5 \%$ & $18,4 \%$ & $15,8 \%$ \\
\hline \multirow{2}{*}{$\begin{array}{c}\text { Questão } \\
9\end{array}$} & 2 & 9 & 17 & 16 & 32 \\
\hline & $2,6 \%$ & $11,8 \%$ & $22,4 \%$ & $21,1 \%$ & $42,1 \%$ \\
\hline \multirow{2}{*}{$\begin{array}{c}\text { Questão } \\
10\end{array}$} & 5 & 13 & 37 & 18 & 3 \\
\hline & $6,6 \%$ & $17,1 \%$ & $48,7 \%$ & $23,7 \%$ & $3,9 \%$ \\
\hline
\end{tabular}

Fonte: As autoras.
Tabela 5: Distribuição de respostas (noite, unidades MM e VM)

\begin{tabular}{|c|c|c|c|c|c|}
\hline & $\begin{array}{c}\text { Em } \\
\text { branco }\end{array}$ & a & b & c & $\mathrm{d}$ \\
\hline \multirow{2}{*}{$\begin{array}{c}\text { Questão } \\
1\end{array}$} & 0 & 46 & 2 & 16 & 1 \\
\hline & $0,0 \%$ & $70,8 \%$ & $3,1 \%$ & $24,6 \%$ & $1,5 \%$ \\
\hline \multirow{2}{*}{$\begin{array}{c}\text { Questão } \\
2\end{array}$} & 0 & 2 & 60 & 0 & 3 \\
\hline & $0,0 \%$ & $3,1 \%$ & $92,3 \%$ & $0,0 \%$ & $4,6 \%$ \\
\hline \multirow{2}{*}{$\begin{array}{c}\text { Questão } \\
3\end{array}$} & 0 & 62 & 0 & 3 & 0 \\
\hline & $0,0 \%$ & $95,4 \%$ & $0,0 \%$ & $4,6 \%$ & $0,0 \%$ \\
\hline \multirow{2}{*}{$\begin{array}{c}\text { Questão } \\
4\end{array}$} & 1 & 4 & 17 & 23 & 20 \\
\hline & $1,5 \%$ & $6,2 \%$ & $26,2 \%$ & $35,4 \%$ & $30,8 \%$ \\
\hline \multirow{2}{*}{$\begin{array}{c}\text { Questão } \\
5\end{array}$} & 0 & 3 & 3 & 20 & 39 \\
\hline & $0,0 \%$ & $4,6 \%$ & $4,6 \%$ & $30,8 \%$ & $60,0 \%$ \\
\hline \multirow{2}{*}{$\begin{array}{c}\text { Questão } \\
6\end{array}$} & 0 & 2 & 4 & 55 & 4 \\
\hline & $0,0 \%$ & $3,1 \%$ & $6,2 \%$ & $84,6 \%$ & $6,2 \%$ \\
\hline \multirow{2}{*}{$\begin{array}{c}\text { Questão } \\
7\end{array}$} & 0 & 1 & 62 & 2 & 0 \\
\hline & $0,0 \%$ & $1,5 \%$ & $95,4 \%$ & $3,1 \%$ & $0,0 \%$ \\
\hline \multirow{2}{*}{$\begin{array}{c}\text { Questão } \\
8\end{array}$} & 2 & 16 & 31 & 11 & 5 \\
\hline & $3,1 \%$ & $24,6 \%$ & $47,7 \%$ & $16,9 \%$ & $7,7 \%$ \\
\hline \multirow{2}{*}{$\begin{array}{l}\text { Questão } \\
9\end{array}$} & 0 & 4 & 7 & 17 & 37 \\
\hline & $0,0 \%$ & $6,2 \%$ & $10,8 \%$ & $26,2 \%$ & $56,9 \%$ \\
\hline \multirow{2}{*}{$\begin{array}{c}\text { Questão } \\
10\end{array}$} & 0 & 10 & 26 & 28 & 1 \\
\hline & $0,0 \%$ & $15,4 \%$ & $40,0 \%$ & $43,1 \%$ & $1,5 \%$ \\
\hline
\end{tabular}

Fonte: As autoras.

Tabela 6: Medidas descritivas do número de acertos verificados, conforme unidade e período

\begin{tabular}{cccccc}
\hline Unidade & Período & Média & Desvio-padrão & Mínimo & Máximo \\
\hline \multirow{2}{*}{ MM } & Noite & 6,3 & 1,6 & 2,0 & 9,0 \\
& Tarde & 6,7 & 1,9 & 2,0 & 10,0 \\
\cline { 2 - 6 } & Total & 6,5 & 1,8 & 2,0 & 10,0 \\
\hline \multirow{2}{*}{ VM } & Manhã & 7,1 & 1,7 & 1,0 & 10,0 \\
& Noite & 6,8 & 1,6 & 4,0 & 10,0 \\
& Tarde & 5,8 & 1,9 & 1,0 & 10,0 \\
\hline \multirow{2}{*}{ Total } & Total & 6,5 & 1,8 & 1,0 & 10,0 \\
& Manhã & 7,1 & 1,7 & 1,0 & 10,0 \\
& Noite & 6,6 & 1,6 & 2,0 & 10,0 \\
& Tarde & 6,2 & 1,9 & 1,0 & 10,0 \\
\cline { 2 - 5 } & Total & 6,5 & 1,8 & 1,0 & 10,0 \\
\hline
\end{tabular}

Fonte: As autoras.

fármacos, respectivamente. Os menores índices de acertos ocorreram nas questões $8(24,6 \%)$, sobre situação de atendimento de emergência, 4
(35,4\%), dos cuidados na administração de drogas, e 10 (40\%), do conhecimento e interpretação de eletrocardiograma. 

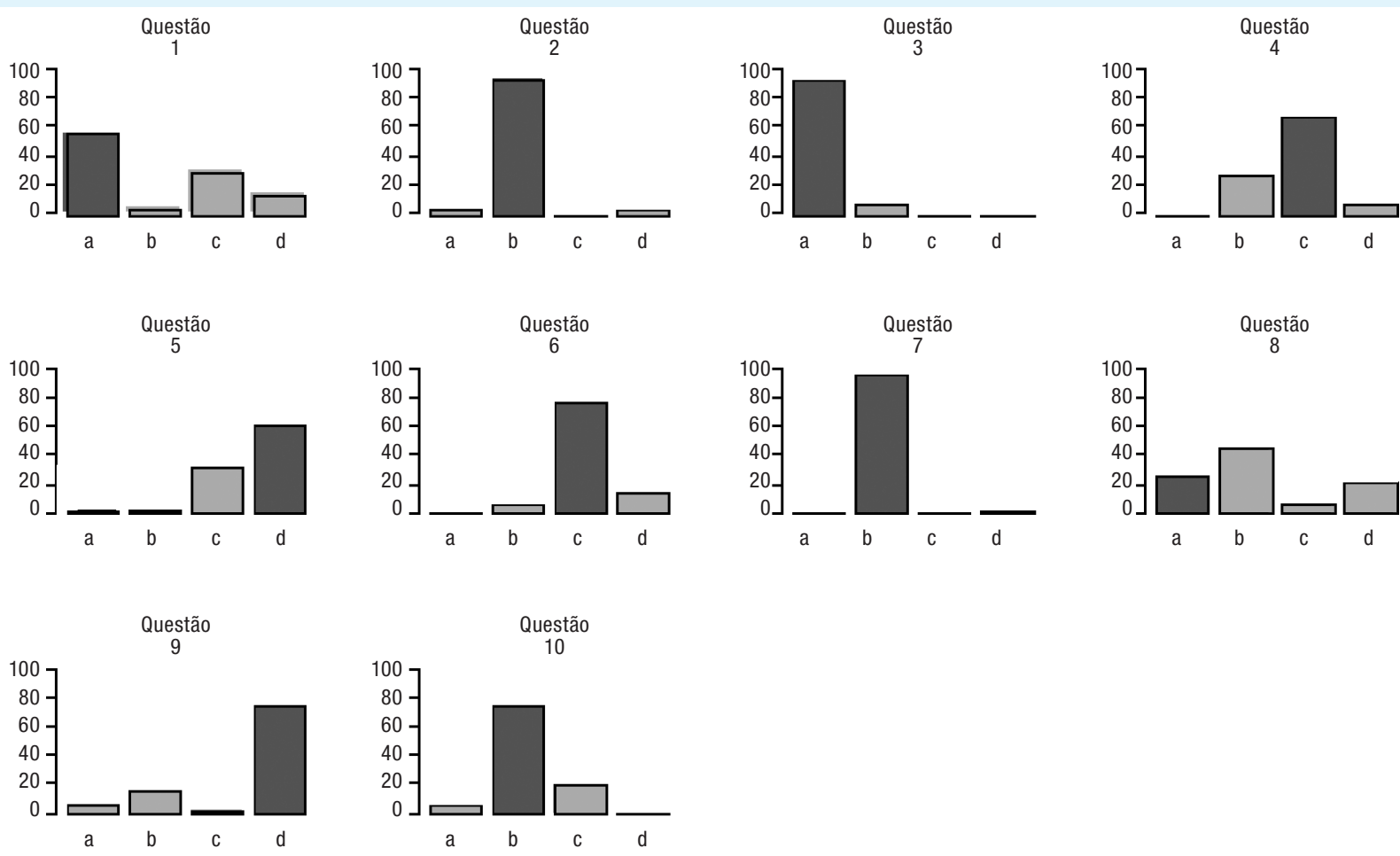

Grófico 3: Acerto de alunos (manhã, unidades MM e VM)

Fonte: As autoras.
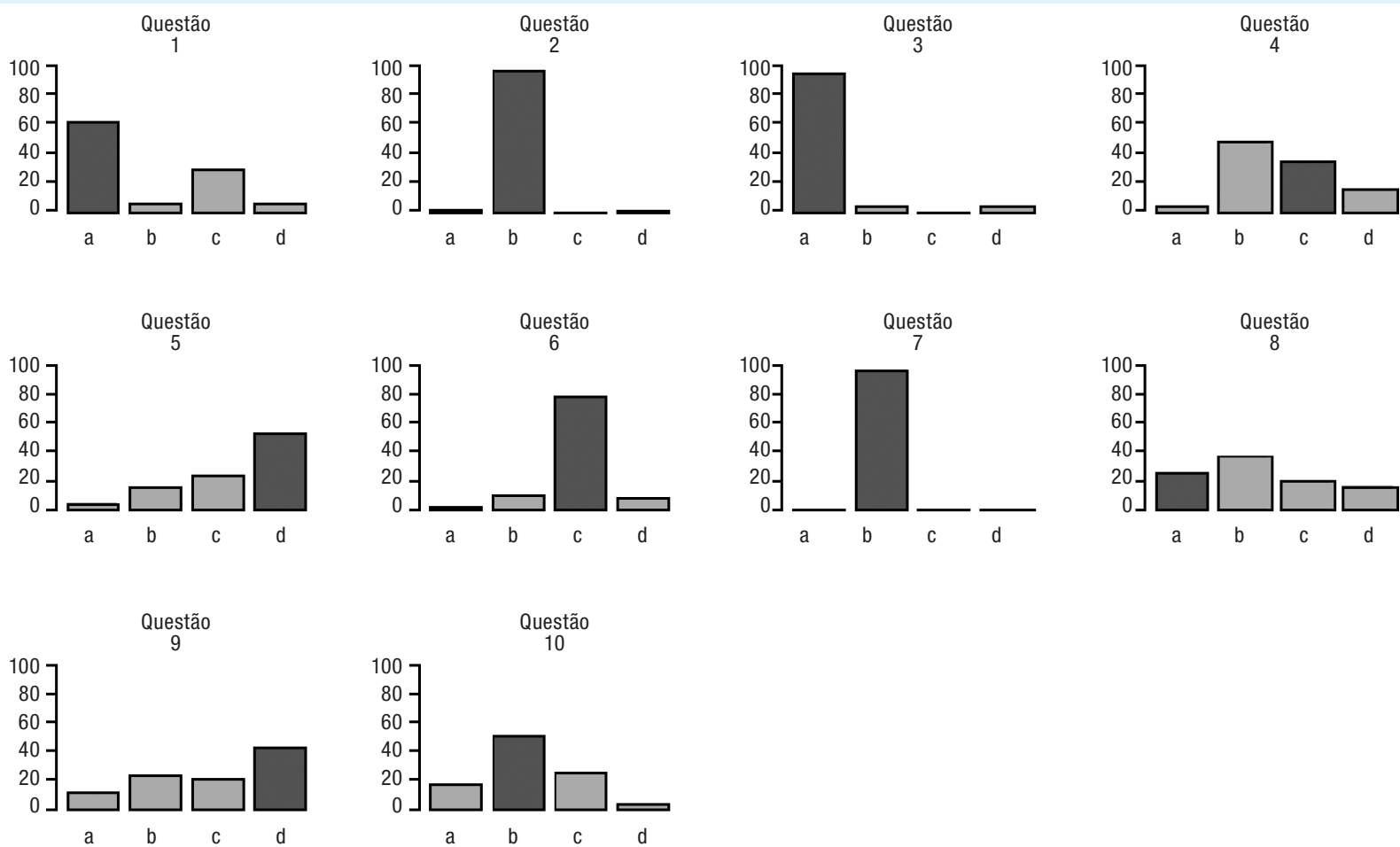

Gráfico 4: Acerto de alunos (tarde, unidades MM e VM)

Fonte: As autoras. 

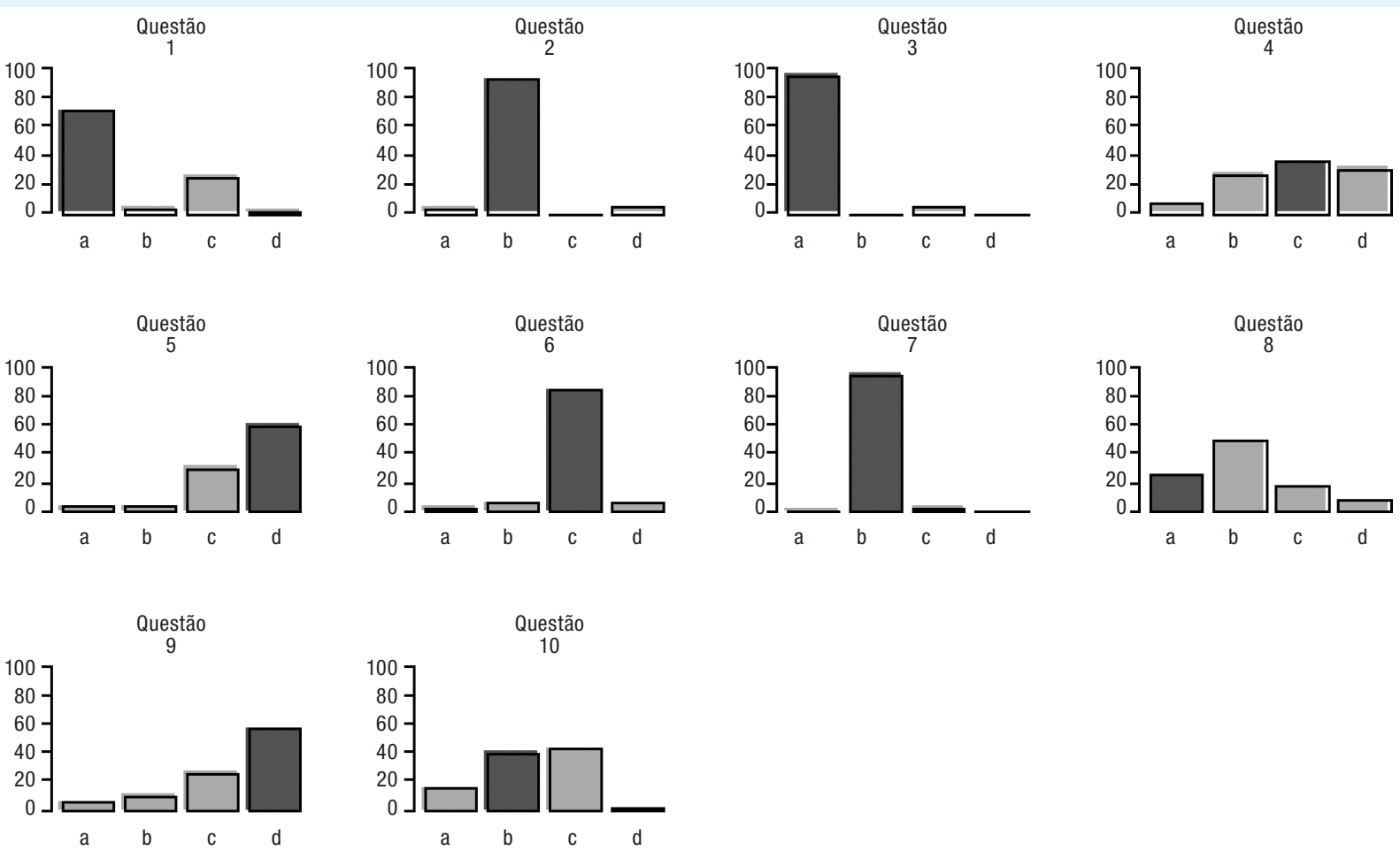

Gráfico 5: Acerto de alunos (noite, unidades MM e VM)

Fonte: As autoras.
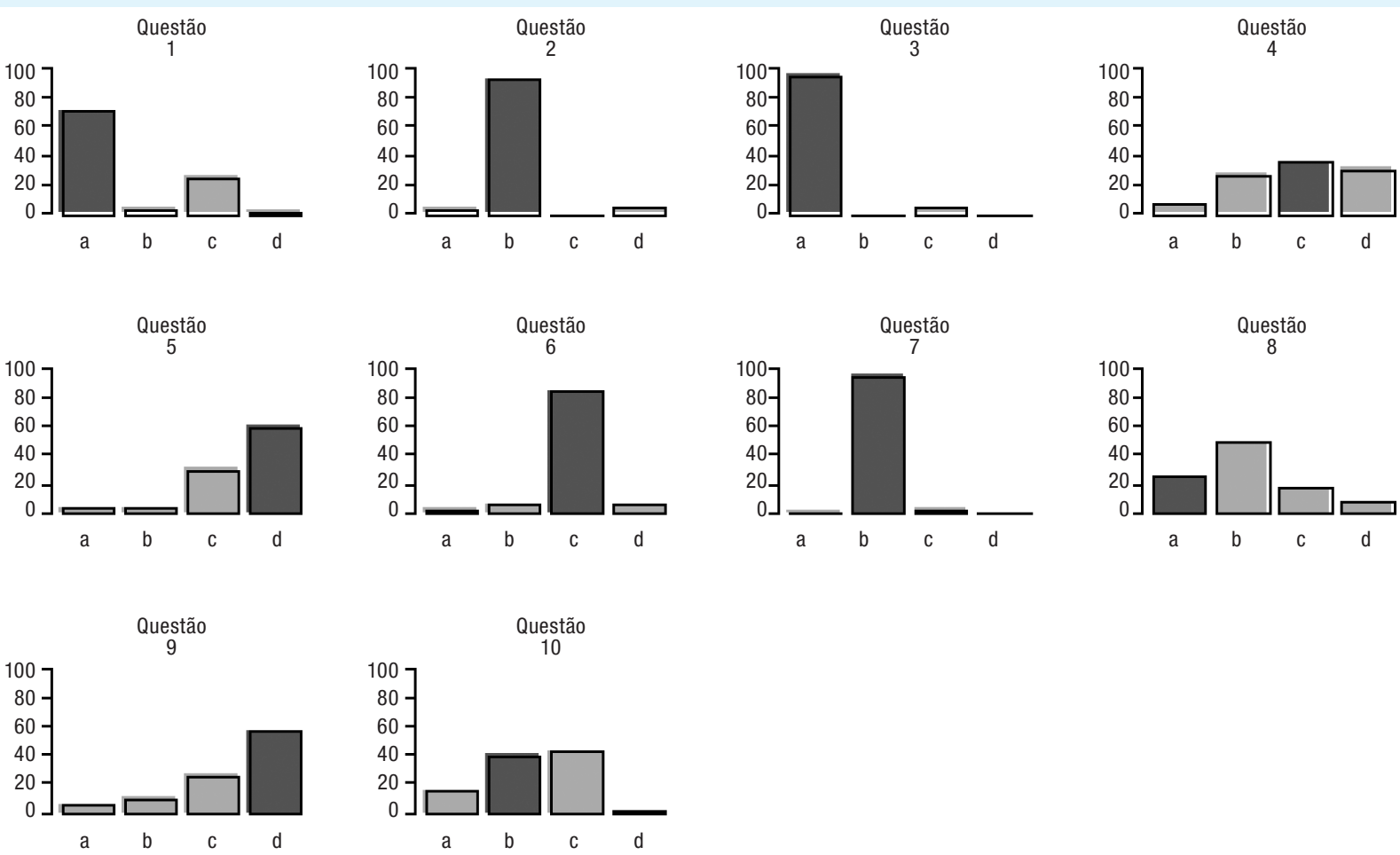

Grófico 6: Respostas de todos os alunos estudados

Fonte: As autoras. 
As respostas obtidas sobre o conhecimento a respeito do nível de energia de descarga elétrica correta a ser aplicada no paciente (questão 6) foram satisfatórias em todas as análises apresentadas.

\section{Discussão}

Verificou-se que a diferença entre os períodos depende da unidade considerada. Entre alunos da unidade Vila Maria não há diferença
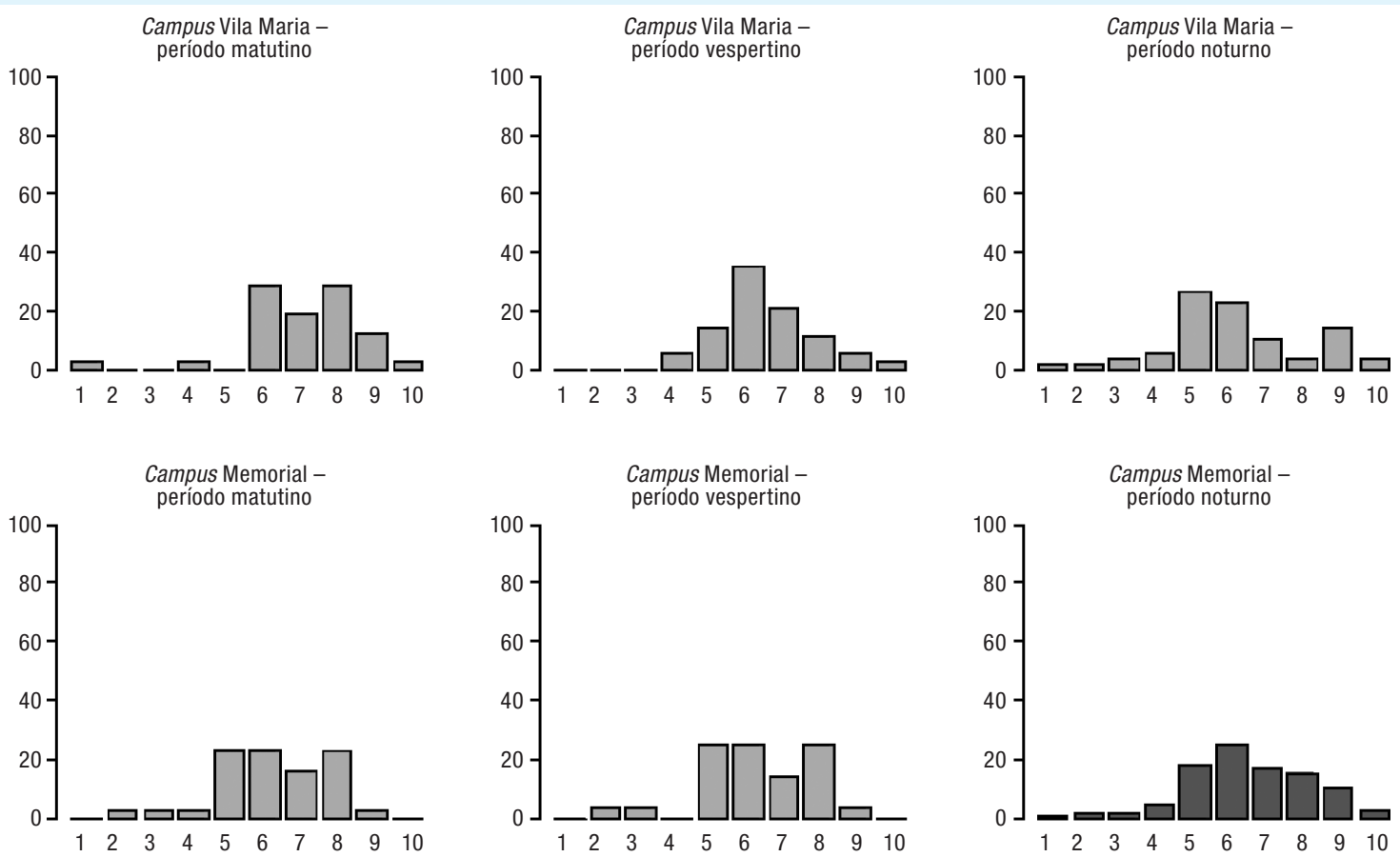

Gráfico 7: Distribuição do número de acertos, conforme unidade e período

Fonte: As autoras.

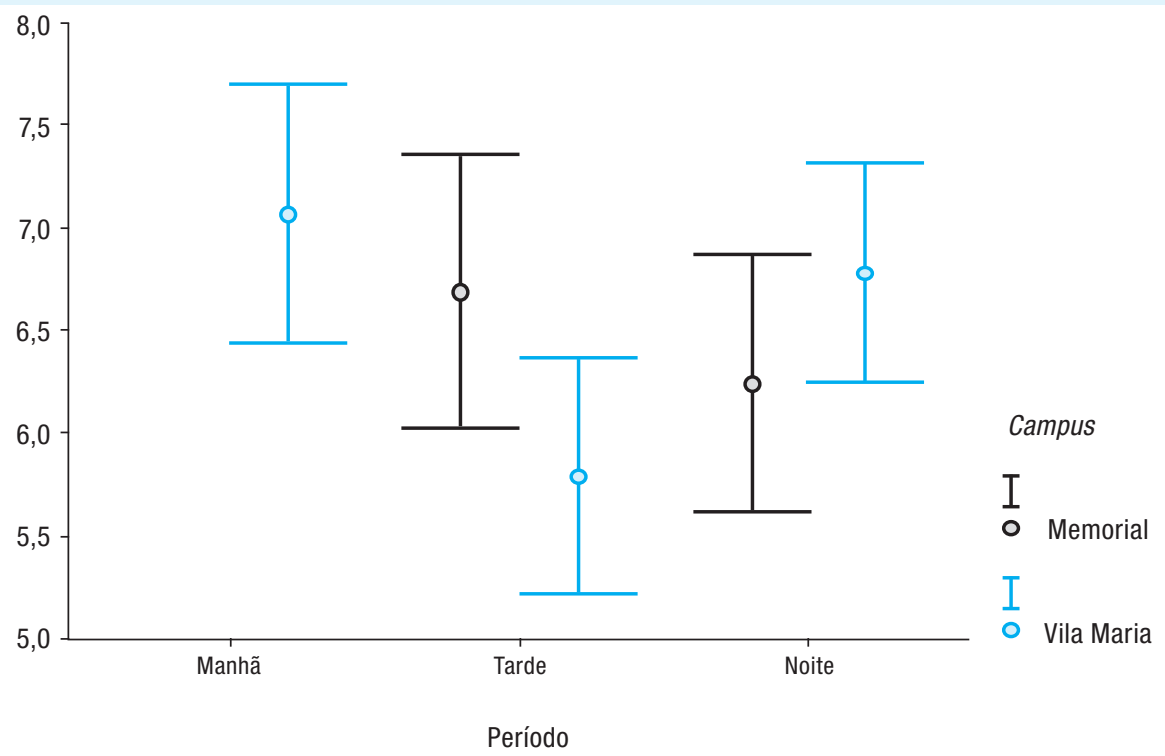

Gráfico 8: Intervalos de confiança para a média do número de acertos, conforme unidade e período

Fonte: As autoras. 
na quantidade de acertos verificada nos períodos matutino e noturno. No período da tarde, no entanto, os acertos ocorreram com menor freqüência do que nos períodos da manhã e noite. Já em relação à unidade Memorial, a quantidade média de acertos observada nos dois períodos considerados é a mesma.

O estudo exploratório-descritivo, com a finalidade de traçar o perfil profissional do aluno que faz um curso específico de Suporte Avançado de Vida em Cardiologia (SAVC), permite constatar que a maioria dos alunos submetidos a esse treinamento pertence à categoria média, ou seja, tende a realizar um melhor prognóstico e atendimento aos pacientes vitimados pela PCR (CARVALHO; LEITÃO, 2004).

Estudo realizado pelo Medical Center of Central Georgia, com enfermeiros que atendiam RCP, revelou que os pacientes em PCR, socorridos por enfermeiros treinados adequadamente no curso, apresentaram nível de sobrevida (38\%) superior ao dos assistidos por enfermeiros sem o referido treinamento. Isso demonstra a importância de os cursos especializados serem divulgados, diante da necessidade de capacitar profissionais para o atendimento dos casos de RCP (CARVALHO; LEITÃO, 2004).

No Brasil, foi realizado estudo na Escola de Enfermagem da Universidade Federal de Minas Gerais (EE-UFMG), no curso de graduação em Enfermagem, para conhecer as abordagens didático-pedagógicas mais seguidas, investigando-se as disciplinas do curso em questão. $\mathrm{O}$ resultado mostrou que havia desconhecimento, por parte de alguns docentes, das concepções pedagógicas adotadas pelo curso, evidenciando contradições entre as concepções metodológicas, a didática e a prática desenvolvidas. Constatou-se a necessidade da adoção de metodologias inovadoras e a diversificação dos cenários de práticas, a partir da implementação de experiências (CHIANCA et al., 2004).

\section{Considerações finais}

Milhares de pessoas morrem, anualmente, de PCR. A maioria das vítimas desse mal não chega sequer ao hospital para receber atendimento emergencial adequado. A partir disso, não é possível concluir que o grande problema esteja na falta de conhecimento do enfermeiro. O profissional de enfermagem deve atuar com agilidade no atendimento de PCR, utilizando com rapidez técnicas adequadas, tomando decisões rápidas, sob pressão, tendo como referência normas do Advanced Cardiologic Life Suport (ACLS) da American Heart Association, a fim de evitar que o paciente tenha seqüelas ou, até mesmo, chegue a óbito. Deve estar apto a trabalhar com diferentes profissionais da saúde, a identificar as condições que provocaram a parada cardíaca e a iniciar o tratamento adequado.

Para um atendimento apropriado, é importante que o profissional de enfermagem aprofunde seu conhecimento por meio de treinamento prático e se atualize constantemente, buscando informações sobre suporte básico e avançado. Esses procedimentos são decisivos para um atendimento eficiente e eficaz ao paciente, prevenindo complicações irreversíveis que podem levá-lo a óbito.

É essencial que o enfermeiro tenha amplo conhecimento e prática para realizar o atendimento a um indivíduo numa parada cardíaca. Um dos papéis específicos do enfermeiro é saber usar adequadamente o basic life suport (BLS) e o advanced cardiologic life suport (ACLS), e todo o seu conhecimento prático-teórico e científico adquirido no decorrer da graduação, estágios e nos cursos extracurriculares.

Ao realizar a pesquisa para verificar o conhecimento dos alunos do oitavo semestre do curso de Enfermagem da Uninove, constatou-se que o índice médio obtido de respostas certas sobre o total de questionários aplicados, segundo a unidade e o período, foi 6,5. Vale enfatizar que, apesar de ser minoria $(3,5)$, a quantidade de erros nas respostas dadas ao questionário 
1) Podemos definir uma parada cardíaca como:

a) Cessação súbita e inesperada dos batimentos cardíacos; o coração pára de bombear o sangue para o organismo e os tecidos começam a sofrer os efeitos da falta de oxigênio;

b) Cessação súbita da circulação sistêmica em um indivíduo com expectativa de restauração da fun-

ção cerebral, não-portador de moléstia crônica intratável ou em fase terminal;

c) Ausência de batimentos cardíacos;

d) O pulmão deixa de respirar e o coração cessa os batimentos.

2) Referente à parada cardíaca podemos afirmar que:

a) Estar consciente é sinal de possível parada cardíaca;

b) Ausência de pulso e de batimentos cardíacos demonstra parada cardíaca;

c) Sem pulso a vítima está em asfixia;

d) A identificação dos batimentos cardíacos é sempre realizada pelas mãos.

3) Em relação à parada cardíaca é correto afirmar:

a) Os neurônios do sistema nervoso central não suportam mais de seis minutos sem oxigênio;

b) O sistema nervoso central resiste muito tempo sem oxigênio;

c) Os neurônios necessitam de baixa pressão para sobreviver;

d) As células nervosas são muito resistentes à falta de oxigênio.

4) Quais os cuidados de Enfermagem na administração de drogas na PCR?

a) Infundir SF 0,9\% 10 mililitros $(\mathrm{mL})$ depois de cada medicação;

b) Após administrar drogas por acesso venoso periférico, durante a PCR, deve-se elevar o membro;

c) As três opções estão corretas;

d) Não administrar adrenalina na mesma via do bicarbonato.

5) O diagnóstico do ritmo cardíaco é fundamental na escolha do tratamento definitivo e específico da parada cardiorrespiratória. A parada cardiorrespiratória pode ocorrer:

a) Somente em FV;

b) Somente em taquicardia ventricular (TV), com ausência de pulso

c) Em atividade elétrica sem pulso (Aesp) e assistolia;

d) Em FV, TV (com ausência de pulso), Aesp e assistolia.

6) Assinale o item correto em relação aos níveis de energia recomendados numa desfibrilação externa em adultos e às subseqüentes desfibrilações:

a) $1^{a}$ desfibrilação: $200 \mathrm{~J} / 2^{a}$ desfibrilação: $250 \mathrm{~J}$ e $3^{\mathrm{a}}$ desfibrilação: $500 \mathrm{~J}$

b) $1^{\text {a }}$ desfibrilação: $250 \mathrm{~J} / 2^{\mathrm{a}}$ desfibrilação: $280 \mathrm{~J}$ e $3^{\mathrm{a}}$ desfibrilação: $360 \mathrm{~J}$;

c) $1^{\text {a }}$ desfibrilação: $200 \mathrm{~J} / 2^{\mathrm{a}}$ desfibrilação: $300 \mathrm{~J}$ e $3^{\mathrm{a}}$ desfibrilação: $360 \mathrm{~J}$;

d) $1^{\text {a }}$ desfibrilação: $360 \mathrm{~J} / 2^{\mathrm{a}}$ desfibrilação: $300 \mathrm{~J}$ e $3^{\mathrm{a}}$ desfibrilação: $200 \mathrm{~J}$

7) Qual o fármaco mais utilizado no tratamento da parada cardiorrespiratória?

a) Propanolol;

b) Epinefrina (adrenalina);

c) Bicarbonato de sódio;

d) Sulfato de magnésio.

8) Assinale a (opção) correta:

1) A pesquisa do pulso deve consumir de 5 a 10 s pela possibilidade de ele ser lento, irregular ou de pouca amplitude.

2) Na presença de pulso, porém com respiração ausente após as duas ventilações iniciais, estas devem ser continuadas na freqüência de uma ventilação a cada 5 s;

3) A pressão aplicada deve ser suficiente para deprimir o esterno de 3,5 a 5 centímetros (cm) no adulto;

4) Os sinais clínicos que indicam PCR são: inconsciência, ausência de movimentos respiratórios e ausência de pulso em grandes artérias;

5) Se não houver dois acessos venosos, a Adrenalina pode ser feita na mesma via do bicarbonato de sódio, desde que seja feito um flash de $10 \mathrm{~mL}$ de SF0,9\% entre as medicações.

a) Todas as assertivas estão corretas;

b) 1 , 3 e 4 estão corretas;

c) 2 e 3 estão incorretas;

d) Todas as assertivas estão incorretas.

9) A seqüência correta do atendimento (durante a) PCR é:

a) Liberação de vias aéreas, avaliação do nível de consciência, ajuda, verificação da respiração (ver, ouvir e sentir), duas ventilaç̃̃es de resgate, verificação do pulso e início das compressões torácicas na ausência batimentos cardíacos.

b) Ajuda, liberação das vias aéreas, verificação da respiração (ver, ouvir e sentir), duas ventilações de resgate, avaliação do nível de consciência, verificação do pulso e início das compressões torácicas na ausência de pulso.

c) Liberação das vias aéreas, avaliação do nível de consciência, ajuda, verificação da respiração (ver, ouvir e sentir), duas ventilações de resgate, verificação do pulso e início das compressões torácicas na ausência de pulso.

d) Avaliação do nível de consciência, ajuda, liberação das vias aéreas, verificação da respiração (ver, ouvir e sentir), duas ventilações de resgate, verificação do pulso e início das compressões torácicas na ausência de pulso.

10) Qual destes itens NÃO é um ritmo chocável?

a) Taquicardia ventricular sem pulso (TVSP);

b) Assistolia;

c) Fibrilação ventricular;

d) Taquicardia ventricular sem pulso e fibrilação ventricular.

ANEXO: Questionário para pesquisa de campo sobre parada cardiorrespiratória

Fonte: Os autores. 
ainda é grande, em se tratando da averiguação do grau de conhecimento dos graduandos. Contudo, pelo resultado geral da pesquisa, pôde-se concluir que os pesquisados demonstraram ter conhecimento suficiente para atender ao indivíduo vítima de PCR.

\section{Knowledge of the collegial student of eighth semester of the course of nursing at Uninove on heart arrest}

The majority of the victims of heart arrest die because non adequate emergency attendance, than it must be fast organized in order to prevent damages neurological (after heart arrest) to the patients. These procedures are decisive for an effective and efficient attendance to the patient preventing irreversible complications that can take the patient to the death. The intention of this study was to identify the knowledge of the students of the final half year of Uninove's Nursing students, relative to the heart arrest attendance, by using the quantitative-descriptive technique, with 172 students of the eighth semester of the Course of Nursing of the Uninove, of units Vila Maria and Memorial. $63 \%$ of the answers were evidenced that had been correct, and 37\%, made a mistake. The analysis of the data made possible to identify that, although represented for a minority of the respondents, the amount of errors is great; however, the students in study theoretically are enabled to take care of individuals with heart arrest.

Key words: Cardiopulmonary resuscitation. Heart arrest. Myocardial infarction.

\section{Referências}

BERGAMO, G. Choques que salvam vidas. Veja, São Paulo, n. 1880, p. $78-82,17$ nov. 2004.

BIBLIOMED. Modalidades da parada cardíaca. In: PEIXOTO, M. S. P.; COSTA, M. P. F. da; URRUTIA, G. I. del C. E. Ressuscitação cardiorrespiratória. Assistência de enfermagem sistematizada. 1. ed. Rio de Janeiro: Revinter, 1998. cap. 2.
BIBLIOMED. O coração: sua anatomia e funções. Site Boa Saúde, 26 jul. 2002. Disponível em: <http://boasaude.uol. com.br/lib/showdoc.cfm?LibCatID=-1\&Search=sua $\% 20$ an atomia $\% 20 \mathrm{e} \% 20$ funcoes \&CurrentPage $=0 \&$ LibDocID $=4165$ \#O\%20sistema\%20elétrico\%20do\%20coração>. Acesso em: 22 set. 2005.

CARVALHO, D. V.; LEITÃO, E. de A. Provedor de suporte avançado de vida em cardiologia: demanda espontânea de cursos. Revista Mineira de Enfermagem, Belo Horizonte, v. 8, n. 1, p. 196-200, 2004. Disponível em: <http://www.enf. ufmg.br/reme/remev8n1.pdf >. Acesso em: 29 nov. 2006.

CHIANCA, T. C. M. et al. Repensando a realidade pedagógica na Escola de Enfermagem da Universidade Federal de Minas Gerais. Revista Mineira de Enfermagem, Belo Horizonte, v. 8, n. 1, p. 201-207, 2004. Disponível em: $<$ http://www.enf.ufmg.br/reme/remev8n1.pdf >. Acesso em: 29 nov. 2006.

CUMMINS, R. O. et al. Suporte avançado de vida em cardiologia. 1. ed. Dallas: American Heart Association, 1997.

GIL, A. C. Como classificar as pesquisas? In: GIL, A. C. Como elaborar projetos de pesquisa. 4. ed. São Paulo: Atlas, 2002. p. 41-57.

INSTITUTO DO CORAÇÃO. Instituto do Coração do Hospital das Clínicas. Morte súbita: o que podemos fazer. Conteúdo Médico. Site Instituto do Coração do Hospital das Clínicas, São Paulo, 2003. Disponível em: <http://www. incor.usp.br/conteudo-medico/geral/morte\%20subita. html>. Acesso em: 13 set. 2005.

KNOBEL, E. Condutas no paciente grave. 2. ed. São Paulo: Atheneu, 1998.

LAKATOS, E. M.; MARCONI, M. A. Técnicas de pesquisa. In: LAKATOS, E. M.; MARCONI, M. A. Fundamentos de metodologia científica. 4. ed. São Paulo: Atlas, 2001. p. 186-187.

MANO, R. Parada cardiorrespiratória e morte súbita cardíaca. Ressuscitação cardiopulmonar e morte súbita. Manuais de Cardiologia, Rio de Janeiro, ano 8, 16 fev. 2005. Disponível em: $<$ http://www. manuaisdecardiologia.med. br/MS/MS1.htm>. Acesso em: 13 set. 2005.

MELO, M. do C. B. de; VASCONCELLOS, M. C. de; TONELLI, H. F. de A. Atendimento à parada cardiorrespiratória na faixa etária pediátrica. Revista Médica de Minas Gerais, Belo Horizonte, v. 14, supl. 1, n. 3, p. S96-S105, 2004. Disponível em: <http://www. smp.org.br/atualizacao/download/revista/ Rev_Med_ Minas\%20Gerais\%202004_14\%20(1\%20Supl\%203)\%20S-96$105 \% 20 \% 20$ parada $\% 20$ cardi orespiratoria.pdf $>$. Acesso em: 18 jan. 2006. 
SANTOS, G. T. dos; ROSSI, G.; JARDILINO, J. R. L. O trabalho científico. In: SANTOS, G. T. dos; ROSSI, G.; JARDILINO, J. R. L. Orientações metodológicas para elaboração de trabalhos acadêmicos. 2. ed. São Paulo: Gion, 2000. p. 36-45.

SEVERINO, A. J. Observações metodológicas referentes aos trabalhos de pós-graduação. In: SEVERINO, A. J. Metodologia do trabalho científico. 21. ed. São Paulo: Cortez, 2000. p. 180-182.

SILVA, S. C. da. A presença de fatores iatrogênicos relacionados ao atendimento a parada cardiorrespiratória na unidade de terapia intensiva. In: CONGRESO INTERNACIONAL DE MEDICINA CRÍTICA EN INTERNET, 1., 1999, s/1. Anais... s/1.: 24 nov. 1999. Disponível em: <http://www.uninet.edu/cimc99/fulltext/ 00149SC/00149SC.html>. Acesso em: 13 set. 2005.

SOCIEDADE BRASILEIRA DE CARDIOLOGIA. Diretriz de apoio ao suporte avançado de vida em cardiologia - Código Azul - registro de ressuscitação - normatização do carro de emergência. Arquivos Brasileiros de Cardiologia, São Paulo, v. 81, n. 4, p. 3-14, 2003. Disponível em: <http:// www.scielo.br/pdf/abc/v81s4/20229.pdf >. Acesso em: 18 jan. 2006.
TIMERMAN, A. et al. Prognostic factors of the results of cardiopulmonary resuscitation in a cardiology hospital. Arquivos Brasileiros de Cardiologia, São Paulo, v. 77, n. 2, p. 142-160, 2001.

WAYNE, R. et al. (Ed.). Hurst's the heart. 9. ed. São Paulo: McGraw-Hill, 1998.

ZAGO, A. C. et al. Ressuscitação cardiorrespiratória: atualização, controvérsias e novos avanços. Arquivos Brasileiros de Cardiologia, São Paulo, v. 72, n. 3, p. 363-374, 1999. Disponível em: <http://publicacoes.cardiol.br/ abc/1999/7203/72030009.pdf>. Acesso em: 18 jan. 2006.

$\mathrm{ZOCH}, \mathrm{T}$. W. et al. Short-and long-term survival after cardiopulmonary resuscitation. Archives of Internal Medicine, Chicago, v. 160, n. 13, p. 1.969-1.973, 2000.
Recebido em 31 jan. 2006 / aprovado em 14 maio 2006

\section{Para referenciar este texto}

REIS, H. H.; FERREIRA, G. M. M. Conhecimento dos graduandos de oitavo semestre do curso de Enfermagem do Centro Universitário Nove de Julho (Uninove) sobre parada cardiorrespiratória. ConScientiae Saúde, São Paulo, v. 6, n. 1, p. 89-103, 2007. 
